Special Issue 特集論文

Invited Peer-Reviewed Article 招待查読論文

\title{
Relationship between Consumer's Hedonic and Utilitarian Motives for Making and the Value of User-Developed Solutions and Sharing of Solutions:
}

\author{
A Large-Scale Empirical Study
}

\section{消費者の功利主義的・快楽主義的モノづくり 動機と, 製品成果・公開 \\ 一大規模サーベイによる実証研究 一}

\author{
Shoo Okada ${ }^{{ }_{1}}$, Hidehiko Nishikawa ${ }^{{ }_{2}}$ \\ ユーザー・イノベーション研究会 企画運営メンバーI \\ 法政大学大学院 経営学研究科 博士後期課程 \\ 岡田 庄生 \\ ユーザー・イノベーション研究会リーダー/法政大学 経営学部

\section{西川 英彦}

\footnotetext{
${ }^{* 1}$ Member of User Innovation Research Workshop / Graduate School of Business Administration, Hosei University, shoo.okada@gmail.com

${ }^{* 2}$ Leader of User Innovation Research Workshop / Faculty of Business Administration, Hosei University, hidehiko@hosei.ac.jp
}

\begin{abstract}
A growing number of consumers are interested in making items, as part of maker culture, and high value product solutions are being created and shared. While several companies have achieved high market performance using these solutions, many consumer solutions have not been used. Under these circumstances, it is important to understand the relationship between the motives of these consumers and the value and sharing of solutions. This helps with market performance provided by consumers' solutions and successful sharing, which is significant not only for researchers and practitioners, but also for social welfare. Many studies have examined these issues, but only in a limited number of consumers, and this behavior in all consumers is still not understood. In this study, we examined the empirical relationship of the motives of consumers with the value of user-developed solutions and sharing of these solutions, using large-scale survey data of consumers. Our findings show that the motives of utilitarian consumers affect the value of user-developed solutions, whereas those of hedonic consumers have an effect on sharing of solutions. The effect on sharing the solutions is strengthened by the motives of utilitarian consumers.
\end{abstract}

Keyword : User innovation, Maker's movement, Innovative product, Intrinsic motivation, Extrinsic motivation

要約 : モノづくりをする消費者が増加し，その中から高い製品成果が創出·公開され，その成果を利用し，市場で成果をあげて いる企業がある一方, 多くの消費者の成果がいまだ活用されていないという現状がある。こうした状況下, 研究者や実務家が, どのようなモノづくり動機をもつ消費者が製品成果をあげ, 製品公開をするのかを理解するということは, 消費者のモノづくり がもたらす市場成果を上手く活用でき, 研究あるいは実務だけでなく, 社会全体にとっても意義がある。こうした問題意識に対 し，多くの先行研究が行われてきたが，限定的な消費者を対象にしていて，増加するモノづくりを行う消費者全体を捉えたもの とはいえない。こうした中，本研究は，消費者全体にまで対象を広げた大規模サ一ベイによって，モノづくりをする一般的な消 費者の中から，どのようなモノづくり動機をもつ消費者が製品成果をあげ，製品公開を行うのかを実証した。その結果，製品成 果に対しては, 消費者の功利主義的モノづくり動機が影響を与えていた。一方, 製品公開に対しては, 快楽主義的モノづくり動 機が影響を与え, 功利主義的モノづくり動機によりその影響は強められていた。

キーワード : ユーザー・イノベーション，メイカーズ・ムーブメント, 革新的製品, 内的動機, 外的動機

Information : Received 1 April 2019; Accepted 8 April 2019 


\section{I. 序章}

\section{1. 消費者のモノづくり}

近年, 料理やガーデニング, 編み物, 裁縫, スクラッ プブック作りなどに加え，3D プリンタなどのデジタル技 術を利用したモノづくりを行う消費者が増加している。 こうしたモノづくりを行う消費者が，写真や動画によっ て，そのプロセスをブログや SNS 等で公開することで, その工夫が周囲に伝染し，まわりの製品開発好きな人々 を刺激する。いわゆる「メイカーズ・ムーブメント」と 呼ばれる現象である (Anderson, 2012)。

こうした現象を後押しするように，3D プリンタやレー ザーカッターなどを簡単な講習を受ければ誰でも使える 会員制のメイカー・スペースが拡大している。そこでは, 多様なモノづくりを行う人々が出会い, アイデアを公開 し, 共にプロジェクトに取り組むオープンなコミュニティ が形成されている (Halbinger, 2018)。さらに, 消費者が 自らモノづくりした製品を公開できるメイカー・フェア という大型展示会イベントも世界中で拡大している (Dougherty \& Conrad, 2016)。

こうした消費者のモノづくりの中から，革新的製品が 生まれている。いわゆる,「ユーザー・イノベーション」 と呼ばれる現象であり，ユーザーが自ら使用する目的で 製品を創造したり改良することで，革新的製品をもたら す（Ogawa, 2013; von Hippel, 2005)。日本人の 3.7\%の消 費者が革新的製品を創出する消費者イノベーターで，自 ら負担する研究開発費は, 国内消費材メーカーによる研 究開発費の約 $13 \%$ にも敵する（von Hippel, Ogawa, \& de Jong, 2011)。さらに, 消費者イノベーターの約 $11 \%$ が，その製品情報を仲間や企業などの他者に公開し，そ の情報公開した消費者の大部分は知的財産権を主張せ ず，誰もがアクセス可能なウェブサイトなどに投稿する など，情報を無料で公開している（von Hippel et al., 2011)。

こうした状況は, 社会全体にとって望ましい傾向であ る。消費者イノベーターと協力し，革新的製品を活用あ るいは創出したいと考える企業にとって，そのような消 費者を発見したり，アイデアを活用しやすくなるからで
ある（Ogawa, 2013）。実際に活用した多くの企業が，成 果をあげている（Lilien, Morrison, Searls, Sonnack, \& von Hippel, 2002; Nishikawa \& Honjo, 2011; Nishikawa, Schreier, Fuchs, \& Ogawa, 2017; von Hippel, 2005)。例え ば，無印良品では，消費者からのアイデアで生み出した 家具製品群は, 社内デザイナーによる同製品群に比べて, 初年度の売上高は 3 倍, 3 年間累計の売上高では 5 倍を 上回る（Nishikawa, Schreier, \& Ogawa, 2013）。

だが, 社会全体としては, 大きな課題が残る。消費者 イノベーターによる革新的製品のうち, わずか $5 \%$ し 仲間や企業などの他者から受け入れられておらず，その 95\%は社会全体で埋もれた資源となっているのだ（von Hippel et al., 2011)。

このようにモノづくりをする消費者が増加し，その中 から高い製品成果が創出・公開され, その成果を利用し, 市場で成果をあげている企業がある一方, 多くの消費者 の成果は活用されていないという現状がある。

\section{2. 消費者のモノづくり動機}

こうした状況下, 研究者や実務家が, どのようなモノ づくり動機をもつ消費者が製品成果をあげ，製品公開を するのかを理解することは, 消費者のモノづくりがもた らす市場成果を上手く活用でき, 研究あるいは実務にとっ て意義があるだけでなく, 社会全体で充分に活用できず 埋もれている資源を活用できるという意味で, 社会的に も意義がある。こうした点が，本稿の問題意識となる。

そもそも, 人間が何らかの活動を行う動機には, 一般 的に, 内的動機と外的動機の 2 つの動機が存在すること が知られている（Deci, 1975; Deci \& Ryan, 1999; Ryan \& Deci, 2000)。内的動機とは, 活動に参加することの楽し さや挑戦する気持ち, そこで得られる自らのスキルの向 上や他者貢献など, 自身の内面から湧き上がる動機を指 す。一方, 外的動機とは, 活動を行った結果得られる報 酬や地位, 名声や賞罰など, 外部から与えられる要因に よって生まれる動機を指す（Ryan \& Deci, 2000）。

メイカー・ムーブメント研究において, 消費者のモノ づくりに関する内的・外的動機についての研究はあるが (Anderson, 2012; Gershenfeld, 2005)，部分的記述にすぎ ないものが多い。加えて, モノづくりコミュニティやメ 
イカー・スペースに参加するモノづくりを活発に行う消 費者に限定されており（Halbinger, 2018; Wolf-Powers et al., 2017)，自宅などで行う個人も含めたモノづくりする 消費者全体を対象とした分析とはいえない。こうした中， Kwon and Lee（2017）は，限定された対象であるものの 定量的分析を行った。モノづくりのオンライン・コミュ ニティの消費者 93 名を対象に, 外的動機がモノづくり の頻度に対して正の影響を与え，内的動機は影響を与え ていないことを実証した。だが，モノづくりによる製品 成果や公開については分析されてはいない。

一方，ユーザー・イノベーション研究に扔てても，消 費者イノベーターという，さらに限定的対象ではあるが, 消費者のモノづくり動機について，定量的分析も含めた 多くの蓄積がある。内的・外的動機と製品成果や公開に 関する多くの研究がある上に（e.g. Franke \& Shah, 2003; Füller, Jawecki, \& Mühlbacher, 2007; Hienerth, von Hippel, \& Jensen, 2014; von Krogh \& von Hippel, 2006)，製品成果 と関連性が高い, 商品選択の購買動機に関連づけた, 功 利主義的・快楽主義的モノづくり動機を使い分析した研 究も実施されている (Füller, 2010; Stock, Oliveira, \& von Hippel, 2015)。消費者の商品選択動機は, 快楽主義的動 機と功利主義的動機の 2 つ分けられるという（Batra＆ Ahtola, 1990; Dhar \& Wertenbroch, 2000; Voss, Spangenberg, \& Grohmann, 2003)。快楽主義的動機とは, 体験的な消費行動のことを指し，楽しさや興奮を期待し た商品購入の動機である。功利主義的動機とは, 機能的 な消費行動のことを指し，機能や性能を期待した商品購 入の動機である。例えば，新しい自動車を購入するとき に，スポーティーなデザインで選択する場合は快楽主義， 燃費や性能で選択する場合は功利主義による意思決定だ という（Dhar \& Wertenbroch, 2000）。

Füller（2010）は，消費者の商品選択動機と，イノベー ションを創出する動機に，次のような関連性を指摘する。 内的動機をもつ消費者は楽しさや娛楽など経験志向の特 徵を持つために快楽主義的であり，外的動機をもつ消費 者は実用的な利益を求める目標志向の特徴を持つために 功利主義的であるという。Stock et al.（2015）は，モ） づくりのプロセスに楽しさを感じ, 経験志向で内的動機 が強い消費者のモノづくり動機を「快楽主義的モノづく
り動機」, 実用的な利益のためにモノづくりを行い，機能 や利便性を好む外的動機が強い消費者のモノづくり動機 を「功利主義的モノづくり動機」と定義した上で，消費 者イノベーターを対象に，それぞれの動機とユーザーが 創り出した製品成果との関係性について分析した。この 研究は，消費者のモノづくり動機を整理し，製品成果と の関倸を提示したという点で大きな貢献がある。だが, 調查対象が限定される上に，モノづくり動機と製品公開 との関係は明らかではなく, 本稿の問題意識に応えるに は至っていない。

そこで，本稿の目的は，消費者の功利主義的モノづく り動機あるいは快楽主義的モノづくり動機と, その製品 成果抢よび公開との関係を，モノづくりを行う消費者を 対象にした大規模サーベイデー夕を用いて，実証的に明 らかにするものである。

\section{II. 先行研究と仮説}

\section{1．消費者のモノづくり動機と製品成果}

関連する先行研究からは, 消費者の功利主義的モノづ くり動機が，製品成果に影響を与えるといえる。

まず，ユーザー・イノベーション研究によれば，消費 者がイノベーションを創出する最大の理由は既存製品へ の不満であり，自分に合った製品を手に入れたいという 動機が強い (von Hippel, 2005)。 Hienerth, von Hippel, and Jensen（2014）は，消費者イノベーター200名を対象に, 5 つの動機（個人的な利用，販売から得られる可能性の ある利益，プロセスに参加する楽しさ，スキルの向上， 他者を助けたい）に 100 ポイントの得点を配分させて, モノづくり動機の相対的な重要性を明らかにしょうとし た。その結果，成果物から得られる利益を優先する外的 動機（個人的な利用, 販売から得られる可能性のある利 益）には全体の約 $62 \%$ の得点が, プロセスに関わる内的 動機（プロセスに参加する楽しさ，スキルの向上，他者 を助けたい) には約 $35 \%$ の得点が振り分けられた。つま り, 製品成果において, 功利主義的モノづくり動機の重 要性は相対的に高いといえる。

Stock et al.（2015）は，消費者イノベーターが持つ快 
楽主義的モノづくり動機の高さが製品の新規性に, 功利 主義的モノづくり動機の高さが製品の有用性に，それぞ れ正の影響を及ぼすことを実証した。つまり，消費者の 功利主義的・快楽主義的モノづくり動機は, 新規性ある いは有用性という製品成果に影響を与えているといえる。 だが, メイカーズ・ムーブメント研究によれば, モノ づくりする消費者の功利主義的モノづくり動機は高いと はいえない。消費者は, 性能の高い製品を得たいといっ た功利主義的モノづくり動機ではなく，モノづくり活動 そのものが持つ楽しさや知的な刺激，スキル向上などの 快楽主義的モノづくり動機によってモノづくりを行うか らである（Anderson, 2012; Gershenfeld, 2005）。

以上より，製品成果をもたらす消費者イノベーターの 功利主義的モノづくり動機は高いといえ, 次の仮説を提 示する。

\section{H1：消費者の功利主義的モノづくり動機の高さが，製 品成果に正の影響を与える}

一方，製品成果に対して，快楽主義的モノづくり動機 は直接影響を与えないという。快楽主義的モノづくり動 機は，モノづくりする消費者全体で高いためである。

メイカーズ・ムーブメント研究によると, 前述したよ うにモノづくりする消費者は, 快楽主義的モノづくり動 機は高い (Anderson, 2012; Gershenfeld, 2005)。 Martinez and Stager（2013）は，モノづくりは自分自身の役に立つ 道具を作るという意味にとどまらず，個人的な自己表現 の一種だと主張する。たとえ作ったものが完璧でなくて も, 所有の喜びを生み出し, 専門家によって完璧に作ら れた同じものよりも愛着を感じるという。Dougherty and Conrad（2016）も，遊び心があり，工夫を楽しみ，好奇 心が強いことがモノづくりする消費者の特徴だと説明す る。このように, 快楽主義的モノづくり動機の重要性が 強調される。さらに，製品成果に関係する創造性の研究 分野においても，楽しさや熱中という動機が創造性を高 めると指摘される (Amabile, 1985; Csikszentmihalyi, 1996; Deci \& Ryan, 1999)。

ユーザー・イノベーション研究においても, 消費者イ ノベーターは, 快楽主義的モノづくり動機が高いといえ
る。ハードウェアやソフトウェアといった製品分野，コ ミュニティやコンテスト形式といった参加形態にかかわ らず，消費者イノベーターは外的動機に加えて, 強い内 的動機を抱いているという（Lakhani \& Wolf, 2003; Leimeister, Huber, Bretschneider, \& Krcmar, 2009; von Krogh \& von Hippel, 2006)。オープンソースソフトウェア のプロジェクトでは, 参加者の内的動機の重要性が指摘 される。プログラムそのものを自分自身が必要だから, より良い仕事やキャリアの昇進を得たいから，という外 的動機だけでなく，コード作成による知的刺激を受けた い，自分自身のプログラミングスキルを向上させたい， プロジェクト参加が楽しいといった内的動機の重要性が 示唆される (Lakhani \& von Hippel, 2003; von Krogh \& von Hippel, 2006)。モノづくりの共創プロジェクトの参加動 機（Füller et al., 2007）や，アイデアコンテストの参加動 機（Leimeister et al., 2009; Zheng, Li, \& Hou, 2011）も, 同様である。プロジェクトの参加者は，製品を必要とす る「ニーズ・ドリブン」だけでなく，プロセスに喜びを 覚える「エキサイティング・ドリブン」の動機も高い (Füller, 2010; Füller et al., 2007)。

このように，モノづくりを行う消費者全体において， 快楽主義的モノづくり動機は高く，製品成果に対して, 快楽主義的モノづくり動機が直接影響を与えるとはいえ ない。一方, 消費者イノベーターとなるには, 功利主義 的・快楽主義的モノづくり動機の両方が重要であること が指摘される。だが， Stock et al.（2015）において，製 品効果に対して, 消費者の功利主義的 - 快楽主義的モノ づくり動機の交互作用は検討されておらず, その両動機 の関係は明確ではないという課題を明らかにする必要も ある。

以上より，消費者の快楽主義的モノづくり動機は，製 品成果に直接影響を与えないが, 功利主義的モノづくり 動機がもたらす影響を強める調整効果をもつといえ, 次 の仮説を提示する。

H2 : 消費者の功利主義的モノづくり動機の高さが製品 成果に与える正の影響は, 快楽主義的モノづくり動機が 高いほど強まる 


\section{2. 消費者のモノづくり動機と製品公開}

次に，製品公開に対しては，消費者の快楽主義的モノ づくり動機が影響を与えると, 先行研究からいえる。

まず, メイカーズ・ムーブメント研究によれば, メイ カーズ・ムーブメントにおける消費者の特徴として, 消 費者がモノづくりを行うだけでなく，モノづくりのプロ セスを文章や写真, 動画などで記録し, ブログや SNS で 積極的に公開することがあげられる（Anderson, 2012; Halverson \& Sheridan, 2014）。Baichtal（2014）は，製品 公開する理由は，自分を表現したい，何かを言いたい， 他人に影響を与えたいという衝動だと説明する。モノづ くりは自己表現の手段であり，自分のアイデアをシェア することで世界へ関与することに喜びを感じると指摘す る。こうした内的動機は, 快楽主義的モノづくり動機だ といえる。

ユーザー・イノベーション研究においても，消費者の 快楽主義的モノづくり動機が，製品公開に影響を与える といえる。Franke and Shah（2003）は，激しいスポーツ のイノベーション・コミュニティを対象に，消費者イノ ベーターが自らの革新的製品を他者と共有する理由は, それ自体が楽しいからだと説明する。消費者は製品を販 売するつもりがないため, 製品情報を隠す理由はなく, むしろ公開することで情報を交換できることが彼ら自身 の楽しみにつながるという。Füller et al.（2007）は，バ スケットシューズのイノベーション・コミュニティを対 象に，消費者イノベーターが情報を公開するのは，活動 自体が楽しくてやりがいがあるから，他者の助けになる ことが嬉しいからという動機をあげる。

以上より，消費者の快楽主義的モノづくり動機が製品 公開に強く影響を与えているといえ，次の仮説を提示 する。

H3 : 消費者の快楽主義的モノづくり動機は，製品公開 に正の影響を与える

一方，製品公開に対して，功利主義的モノづくり動機 は直接影響を与えないといえる。多くのモノづくりを行 う消費者にとって，製品公開と功利主義的モノづくり動 機とは，関係がないからである。
ユーザー・イノベーション研究では，多くの消費者イ ノベーターが公開に理由をもたないという。Ogawa and Pongtanalert（2013）は，消費者イノベーターを対象に， コミュニティ所属の有無と製品公開の動機の関係を分析 した。消費者イノベーター 577 名中, コミュニティ所属 イノベーターが 43 名 $(7 \%)$, 単独イノベーター（コミュ ニティ非所属）が 534 名（93\%）であり，製品公開はコ ミュニティ所属イノベーターの $86 \%$, 単独イノベーター の $63 \%$ が実施していた。製品公開の理由（複数選択可） は，コミュニテイ所属イノベーターの多くが「他者から の承認を得たい $(54 \%) 」$, 「他の人の意見によって自分

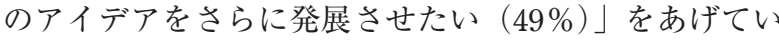
るのに対して，単独イノベーターの多くが「特に理由な く，他者からの賞賛や見返りの期待もなく（52\%）」を あげていた。快楽主義的モノづくり動機と関係があるよ うな質問の選択肢がないため, その関係までは正確に理 解できないが, 大多数を占める個人の消費者イノベーター の製品公開において, 功利主義的モノづくり動機は関係 がない上に，特に理由などないのである。だが，製品公 開には，功利主義的・快楽主義的モノづくり動機の両方 が関係することも指摘される。Franke and Shah（2003） は, 前述したように, 快楽主義的モノづくり動機と製品 公開の関係を指摘するだけでなく，自ら作成した製品に 対して他者から手助けを得られるという，功利主義的モ ノづくり動機といえる動機の存在を説明する。

メイカー・ムーブメント研究においては, 多くのモノ づくり消費者の製品公開と, 功利主義的モノづくり動機 の関係は不明であるが，ユーザー・イノベーション研究 同様に, コミュニティに所属する消費者には, 功利主義 的モノづくり動機がみられる。Dougherty and Conrad （2016）は,「メイカー・フェア」で自分の制作物を披露 する消費者の動機は, 他者からの手助けを得られる, そ して自分の創造性や技術の高さを周りの人に自慢したい と説明する。その一方, ユーザー・イノベーション研究 と同様に，製品公開には，快楽主義的・功利主義的モノ づくり動機の両方が関係することも指摘される。Baichtal （2014）は，前述したように，快楽主義的モノづくり動 機の製品公開との関係を指摘する一方，自分の作ったも のやその貢献によって他者からの尊敬を得たい, 認知さ 
れたいという承認欲求があるとし，功利主義的モノづく り動機といえる動機との関係を示唆する。

以上より，消費者の功利主義的モノづくり動機は，製 品公開に直接影響を与えないが, 快楽主義的モノづくり 動機がもたらす影響を強める調整効果をもつといえ，次 の仮説を提示する。

H4：消費者の快楽主義的モノづくり動機が製品公開に 与える正の影響は, 功利主義的モノづくり動機が高いほ ど強まる

以上 4 つの仮説を整理すると, 消費者の功利主義的 · 快楽主義的モノづくり動機と, 製品成果・公開との関係 の仮説モデルは図 1 のようになる。

\section{III. 研究方法}

\section{1. 調査概要}

本研究では, 調査会社（マクロミル）の調査パネルを 対象にネットによる大規模サーベイを，2018 年 1 月 16 日から 19 日まで実施した。

まず事前調査として，「過去 3 年以内に，ご自身（な いしは家族）で使用するために, 道具やアクセサリー, 雑貨, 玩具, 服飾, スポーツ用品, 車, 家事で使う器具, ソフトウェアなどのモノづくりの経験はありますか」と いう質問（Ogawa \& Pongtanalert, 2011）により，60,000 サンプルの有効回答を得た。そのうち,「はい」と回答し
たのは 12,643 サンプルであった。つまり, 日本人のおお よそ 5 人に 1 人が，モノづくり経験があることになる。 そのサンプルに対して, 本調査を依頼し,「総務省統計局 平成 28 年度国税調査結果」に基づいた人口構成比に割 り付けた 2,070 サンプルの回答を得た時点で調査を終了 した。さらに，不完全な回答を除き，2,002 サンプルを 対象に分析を行った。

\section{2. 尺度}

（1）従属変数

1 つめの従属変数は, 製品成果 $($ 有 $=1$, 無 $=0$ ) であ り，ユーザー・イノベーションといえる水準かどうかを 2 段階で判断した（Ogawa \& Pongtanalert, 2011）。第 1 段 階は, 被験者自身の回答に基づき判定が行われた。まず は,「自身がモノづくりした製品と同様の機能を持った製 品を市場で手に入れることはできますか」という質問に 「はい」と答えたサンプルを除き, 次に「あなたが最近モ ノづくりした製品は, 市場で入手可能な既存製品には無 い新しい機能を含んでいますか」,「あなたが最近モノづ くりした製品は，市場で入手可能な既存製品の機能より も高い機能を含んでいますか」という質問のどちらとも に「いいえ」と答えたサンプルを除き, 最後に「あなた が最近モノづくりした製品は, 自分の仕事の業務のため に行なったものですか」という質問に「はい」を選んだ サンプルを除き，570 サンプルを自己申告の製品成果あ りとした。

第 2 段階は, 570 サンプルの製品詳細の自由回答を, イノベーションのコンサルティング業務に精通した 2 名 
に依頼し，新機能や高い機能性が欠如しているもの（例 えば, PCの既製品のソフトフェアを買ってきてアップ グレードした）を成果なしと判断して除き，製品成果あ り（n=177）と，成果なし $(n=1,825)$ に分類した。

もう 1 つの従属変数は, 製品公開 $($ 有 $=1$, 無 $=0)$ である。「あなたは, 最近モノづくりした製品について, 他の人や企業に対して，無料または有料で見せたり，話 したりして伝えましたか」という質問を行い，製品公開 あり $(\mathrm{n}=691)$ と，公開なし $\left(\mathrm{n}=1,311 ） に\right.$ 分類した ${ }^{1)}$ 。

\section{（2）独立変数}

独立変数は, 消費者の功利主義的 - 快楽主義的モノづ くり動機の 2 つの概念である。消費者の功利主義的モノ づくり動機に関する概念は 6 項目，快楽主義的モノづく り動機に関する概念は 6 項目を使い（Stock et al., 2015; Voss et al., 2003)，リッカート 7 点尺度（1＝全く当ては まらない, 7 = 非常に当てはまる) を用いて測定する（表 1)。

\section{（3）コントロール変数}

製品成果に対するコントロール変数としては，5 変数 を利用する。まず，消費者のモノづくりの専門スキルに 関する概念は 3 項目を使い (Füller, Matzler, \& Hoppe, 2008; Stock et al., 2015)，リッカート 7 点尺度（1 = 全く 当てはまらない， 7 =非常に当てはまる）を用いて測定 した（表 1$)$ 。次に，モノづくり費用（材料費・交通費· 機材費・レッスン費などの合計金額）は，その実数（円） を測定する（Stock et al., 2015）。続いて，回数が多いほ ど製品成果向上の可能性があるため，過去 3 年間のモノ づくりの回数 (実数) を利用する。さらに, 年齢 (実数), 性別（男 $=1$ ，女 $=0 ）$ も利用する。

製品公開に対するコントロール変数としては，5変数 を利用する。年齢, 性別, 過去 3 年間のモノづくり回数 に加え，コミュニティ所属（有 $=1 ，$ 無 $=0 ）$ と，製品 成果 $($ 有 $=1$, 無 $=0$ ）を利用する。コミュニティ所属 の消費者のほうが情報公開を行いやすい可能性が高く (Ogawa \& Pongtanalert, 2013)，そして，製品成果の結果

\begin{tabular}{|c|c|c|c|c|}
\hline 概念 項目 & $\begin{array}{l}\text { 標準化 } \\
\text { 係数 }\end{array}$ & $\alpha$ & $\mathrm{CR}$ & AVE \\
\hline \multicolumn{5}{|l|}{1 功利主義的モノづくり動機 } \\
\hline モノづくりが, 有効だから & $.82^{* * *}$ & .92 & .92 & .67 \\
\hline モノづくりが, 役立つから & $.89^{* * *}$ & & & \\
\hline モノづくりが，実用的だから & $.85^{* * *}$ & & & \\
\hline モノづくりが, 必要だから & $.80^{* * *}$ & & & \\
\hline モノづくりが, 現実的だから & $.85^{* * *}$ & & & \\
\hline モノづくりが, 問題を解決してくれるから & $.70^{* * *}$ & & & \\
\hline \multicolumn{5}{|l|}{2 快楽主義的モノづくり動機 } \\
\hline モノづくりが, 遊びだから & $.70^{* * *}$ & .92 & .92 & .66 \\
\hline モノづくりが, エキサイティングだから & $.68^{* * *}$ & & & \\
\hline モノづくりが, 面白いから & $.91^{* * *}$ & & & \\
\hline モノづくりが, 刺激的だから & $.73^{* * *}$ & & & \\
\hline モノづくりが, 楽しいから & $.91^{* * *}$ & & & \\
\hline モノづくりが, 喜びだから & $.88^{* * *}$ & & & \\
\hline \multicolumn{5}{|l|}{3 モノづくり専門スキル } \\
\hline 以前より，こうした製品の問題点を解決するための十分な知識を持っていた & $.91^{* * *}$ & .94 & .94 & .84 \\
\hline 以前より，こうした製品の問題点についての深いノウハウを持っていた & $.94^{* * *}$ & & & \\
\hline 以前より，こうした製品の問題点について十分に理解していた & $.89^{* * *}$ & & & \\
\hline$\chi^{2}(\mathrm{df}=87, p<.000)$ & $2,217.44$ & & & \\
\hline CFI & .92 & & & \\
\hline GFI & .86 & & & \\
\hline
\end{tabular}

CR, Composite Reliability; AVE, Average Variance Extracted; $* * * p<.001$ ，概念間相関係数 1-2 間 $0.457,1-3$ 間 0.341 , 2-3 間 0.194, 全て $p<.001$ 
も公開に影響を与える可能性があるからである。

\section{3. 信頼性と妥当性}

まず，構成概念となる功利主義的・快楽主義的モノづ くり動機, 専門スキルの 15 項目の変数に対して, 探索 的因子分析（最尤法，プロマックス回転）を行った。因 子負荷量の基準を 0.40 以上，共通性の基準を 0.40 以上 として各項目を調べたところ，いずれも数值を十分に満 たし，累積因子寄与率も 0.50 を超えていた。

構成概念の評価として, 信頼性と妥当性を確認する (表 1)。まず，信頼性については，クロンバック $a$ 係数は 0.8 以上あり, CR（Composite Reliability）も0.6 以上で あり, 構成概念は内的一貫性を備えている（Bagozzi \& Yi, 1988)。

続いて, 確認的因子分析によって構成概念の妥当性を 確認する。まず, 一次元性については, GFI=0.86, $\mathrm{CFI}=0.92$ となり, 適合度が十分に高いとはいえないが, 先行研究でも利用されたモデルでもあり採用した（Stock et al., 2015）2。収束妥当性については，各構成概念に対 して，すべての項目で標準化係数（因子負荷量）が有意 であり，かつ 0.5 を超えている（Hair, Black, Babin, \& Anderson, 2010)。すべての AVE (Average Variance Extracted）は 0.5 以上であり，十分な妥当性を示してい る（Hair et al., 2010）。弁別妥当性については，それぞれ の構成概念の AVE が, 構成概念間の相関係数の平方を上 回っており，十分な妥当性を示している（Fornell \& Larcker, 1981)。

表 2 は, この分析に含まれる変数の記述統計量と相関
係数を示す。多重共線性に関する重大な懸念は示されて いない。VIF (Variance inflation factors) は, 一般的に使 用されている基準よりも低かった（Hair et al., 2010）。

\section{IV. 分析結果}

\section{1．消費者のモノづくり動機と製品成果の結果}

ロジスティック回帰分析を利用し, 仮説を検定する (表 3）。なお, 交互作用項に使う変数のスコアをそのまま利 用すると, 主効果の変数との相関関係が強くなるため, 功利主義的モノづくり動機と快楽主義的モノづくり動機 は，それぞれ平均值からの偏差であるセンタリングした スコアを利用する（Aiken \& West, 1991; Cronbach, 1987）。 さらに, 下位検定のため, コントロール変数もセンタリ ングしたスコアを利用する。

分析の結果, 功利主義的モノづくり動機の偏回帰係数 は有意で正の関係 $(b=.58, p<.001)$ であった（モデル 1)。よって, 仮説 1 は採択された。つまり, 消費者の功 利主義的モノづくり動機の高さが, 製品成果に正の影響 を与えるといえる。一方, 快楽主義的モノづくり動機は, 製品成果に直接影響を与えていなかった $(b=-.04, p=.60)$

次に, 製品成果に対する功利主義的 - 快楽主義的モ) づくり動機の交互作用についてみると（モデル 2), 偏回 帰係数は有意ではなかった $(b=.04, p=.50)$ 。したがっ て, 仮説 2 は萧却された。つまり, 消費者の功利主義的 モノづくり動機の高さが製品成果に与える正の影響は, 快楽主義的モノづくり動機が高いほど強まるとはいえ

表 2 記述統計量と相関関係

\begin{tabular}{lrrrrrrrrrr}
\hline & Mean & S.D. & 1 & 2 & 3 & 4 & 5 & 6 & 7 & 8 \\
\hline 1 功利主義的モノづくり動機 & 4.85 & 1.13 & 1 & & & & & & & \\
2 快楽主義的モノづくり動機 & 4.95 & 1.17 & .390 & 1 & & & & & & \\
3 モノづくり専門スキル & 3.78 & 1.39 & .338 & .210 & 1 & & & & & \\
4 男性 & 0.48 & 0.50 & .070 & -.034 & .176 & 1 & & & & \\
5 年齢 & 48.86 & 16.97 & .222 & .092 & .173 & -.019 & 1 & & & \\
6 モノづくり金額 & 21.59 & 231.84 & .054 & .039 & .071 & .045 & .021 & 1 & & \\
7 モノづくり回数 & 14.04 & 45.64 & .038 & .120 & .089 & -.115 & .127 & .007 & 1 & \\
8 コミュニテイ所属 & 0.12 & 0.32 & .028 & .105 & .098 & -.015 & .041 & .024 & .141 & 1 \\
9 製品成果 & 0.09 & 0.28 & .174 & .047 & .079 & .175 & .117 & .004 & -.032 & .006 \\
\hline
\end{tabular}

|.047|以上の相関関係は, $p<.05$ で有意 


\begin{tabular}{|c|c|c|c|c|c|c|}
\hline & \multicolumn{3}{|c|}{ モデル 1} & \multicolumn{3}{|c|}{ モデル 2} \\
\hline & $b$ & S.E. & $\operatorname{Exp}(B)$ & $b$ & S.E. & $\operatorname{Exp}(B)$ \\
\hline \multicolumn{7}{|l|}{ 独立変数： } \\
\hline 功利主義的モノづくり動機 & $.58^{* * *}$ & .09 & 1.78 & $.58^{* * *}$ & .09 & 1.79 \\
\hline 快楽主義的モノづくり動機 & -.04 & .08 & .96 & -.07 & .09 & .93 \\
\hline \multicolumn{7}{|l|}{ 交互作用： } \\
\hline 功利主義 ×快楽主義 & & & & .04 & .06 & 1.04 \\
\hline \multicolumn{7}{|l|}{ コントロール変数： } \\
\hline モノづくり専門スキル & -.05 & .06 & .96 & -.05 & .06 & .95 \\
\hline 男性 & $1.35^{* * *}$ & .19 & 3.85 & $1.35^{* * *}$ & .19 & 3.84 \\
\hline 年歯令 & $.02^{* * *}$ & .01 & 1.02 & $.02^{* * *}$ & .01 & 1.02 \\
\hline モノづくり金額 & .00 & .00 & 1.00 & .00 & .00 & 1.00 \\
\hline モノづくり回数 & .00 & .00 & 1.00 & .00 & .00 & 1.00 \\
\hline 定数 & $-2.75^{* * *}$ & .11 & .06 & $-2.77^{* * *}$ & .11 & .06 \\
\hline McFadden $R^{2}$ & & .12 & & & .12 & \\
\hline-2 対数尤度 & & $1,055.81$ & & & $1,055.37$ & \\
\hline
\end{tabular}

従属変数 $: 1=$ 製品成果あり, $0=$ 製品成果なし, $\mathrm{n}=2,002 ; * * * \mathrm{p} \leq .001$

表 4 製品公開に対するモノづくり動機（ロジスティック回帰分析）

\begin{tabular}{|c|c|c|c|c|c|c|}
\hline & \multicolumn{3}{|c|}{ モデル 1} & \multicolumn{3}{|c|}{ モデル 2} \\
\hline & $b$ & S.E. & $\operatorname{Exp}(B)$ & $b$ & S.E. & $\operatorname{Exp}(B)$ \\
\hline \multicolumn{7}{|l|}{ 独立変数： } \\
\hline 功利主義的モノづくり動機 & .02 & .05 & 1.02 & .02 & .05 & 1.02 \\
\hline 快楽主義的モノづくり動機 & $.19^{* * *}$ & .05 & 1.21 & $.19^{* * *}$ & .05 & 1.21 \\
\hline \multicolumn{7}{|l|}{ 交互作用： } \\
\hline 功利主義 $\times$ 快楽主義 & & & & $.05^{\dagger}$ & .03 & 1.05 \\
\hline \multicolumn{7}{|l|}{ コントロール変数： } \\
\hline 男性 & -.13 & .10 & .88 & -.14 & .10 & .87 \\
\hline 年齢 & $-.01^{* * *}$ & .00 & .99 & $-.01^{* * *}$ & .00 & .99 \\
\hline コミュニティ所属 & $1.17^{* * *}$ & .15 & 3.21 & $1.15^{* * *}$ & .15 & 3.17 \\
\hline モノづくり回数 & $.00^{\dagger}$ & .00 & 1.00 & $.00^{\dagger}$ & .00 & 1.00 \\
\hline 製品成果 & .03 & .18 & 1.03 & .03 & .18 & 1.03 \\
\hline 定数 & $-.69^{* * *}$ & .05 & .50 & $-.72^{* * *}$ & .05 & .49 \\
\hline McFadden $R^{2}$ & & .05 & & & .05 & \\
\hline-2 対数尤度 & & $2,462.28$ & & & $2,459.34$ & \\
\hline
\end{tabular}

従属変数 $: 1=$ 製品公開あり, $0=$ 製品公開なし, $\mathrm{n}=2,002 ; * * * p<.001,{ }^{\dagger} p<.10$

ない。

\section{2. 消費者のモノづくり動機と製品公開の結果}

ロジスティック回帰分析を利用し, 仮説を検定する (表 4)。先と同様に, 功利主義的・快楽主義的モノづくり動 機，コントロール変数はセンタリングして利用する。 分析の結果, 快楽主義的モノづくり動機の偏回帰係数 は有意で正の関係 $(b=.19, p<.001)$ であった（モデル
1）。よって，仮説 3 は採択された。つまり，消費者の快 楽主義的モノづくり動機は，製品公開に正の影響を与え るといえる。

次に，製品公開に対する功利主義的 - 快楽主義的モノ づくり動機の交互作用についてみると（モデル 2), マー ジナルなものの有意で正の関係であった（ $b=.05, p=$. 08）。交互作用項が有意であったため，モデル 2 をもと に，単純傾斜分析法で検定する（Aiken \& West, 1991）。 
功利主義的モノづくり動機の高低（平均 \pm 1 標準偏差） の場合において, 快楽主義的モノづくり動機が製品公開 に与える影響を分析する（Cohen \& Cohen, 1983）。功利 主義的モノづくり動機が高い場合の快楽主義的モノづく り動機の偏回帰係数 $(b=.25, p<.001)$ のほうが, 低い 場合の偏回帰係数 $(b=.14, p<.05)$ に比べて, 製品公開 に与える正の影響が強かった。つまり，消費者の快楽主 義的モノづくり動機が製品公開に与える正の影響は, 功 利主義的モノづくり動機が高いほど強まるといえる。し たがって，仮説 4 は採択された。

\section{V. 結章}

\section{1. まとめ}

モノづくりをする消費者が増加し，その中から高い製 品成果が創出・公開され，その成果を利用し，市場で成 果をあげている企業がある一方，多くの消費者の成果が いまだ活用されていないという現状がある。こうした状 況下，研究者や実務家が，どのようなモノづくり動機を もつ消費者が製品成果をあげ，製品公開をするのかを理 解するということは，消費者のモノづくりがもたらす市 場成果を上手く活用でき，研究あるいは実務にとって意 義があるだけでなく，社会全体で充分に利用できず埋も れている資源を活用できるという意味で，社会的にも意 義がある。こうした問題意識に対し，多くの先行研究が 行われてきたが, 限定的な消費者を対象にしていて, 増 加するモノづくりを行う消費者全体を捉えたものとはい えない。さらに，モノづくり動機と製品公開との関係も 明らかにされていない。

こうした中，本研究は，消費者全体にまで対象を広げ た大規模サーベイによって，モノづくりをする一般的な 消費者の中から，どのようなモノづくり動機をもつ消費 者が製品成果をあげ，製品公開を行うのかを実証した。 製品成果に対しては，消費者の功利主義的モノづくり動 機が影響を与えていた。だが，快楽主義的モノづくり動 機が，その影響を強めるという調整効果をもつとはいえ なかった。一方，製品効果に対しては，消費者の快楽主 義的モノづくり動機が影響を与えていた。さらに，功利
主義的モノづくり動機がその影響を強めるという調整効 果をもつといえた。

\section{2. 貢献}

本研究の学術的貢献として, 2 点を挙げる。第 1 に, ユーザー・イノベーション研究と, メイカーズ・ムーブ メント研究における知見を統合した点である。消費者の モノづくり動機や，製品成果・公開との関係に対して, ユーザー・イノベーション研究では, 消費者イノベーター を対象に多くの定量的研究が蓄積され, メイカーズ・ムー ブメント研究では，モノづくりをする消費者全体を捉え るものの主に定性的研究が展開されるなど, それぞれ独 自に研究が進められてきたのである。こうした両研究の 先行研究レビューを通して, 知見を整理し, 新たな仮説 モデルを構築できたことは，学術的に意義がある。第 2 に, 消費者のモノづくり動機と製品成果 - 公開との関係 をモノづくりを行う消費者への大規模サーベイを通して, 実証的に解明ができたことは，資料的に価值がある。消 費者イノベーターを対象にしたユーザー・イノベーショ ン研究だけでなく，メイカーズ・ムーブメント研究にお いてもモノづくりコミュニテイ所属の消費者という限定 された対象にしか, いままで分析が実施されていなかっ たのである。

次に，実践的貢献として，2 点を挙げる。第 1 に, 消 費者からの製品成果を求めたいと考える企業にとっては, モノづくりの実用性や既存製品の問題点を伝えるなど消 費者が持つ功利主義的モノづくり動機を刺激することで, より功利主義的モノづくり動機が高い消費者の参加を促 したり，そのアイデアを優先したりすることが効果的で あろう。第 2 に，消費者の製品公開を上手く活かしたい と考える企業にとっては，モノづくりプロセスにコミュ ニティやゲーム要素を加えるなど，消費者が持つ快楽主 義的モノづくり動機を刺激することで，より快楽主義的 モノづくり動機が高い消費者を意識的に集めたり，その 消費者を優先したりすることが効果的であろう。併せて, 功利主義的モノづくり動機を刺激することが, 調整効果 をもたらす。 


\section{3. 限界と将来の研究}

まず第 1 に，快楽主義的モノづくり動機が，功利主義 的モノづくり動機が製品成果にもたらす影響を強めると いう調整効果がないとは，必ずしもいえないことである。 単に，ユーザー・イノベーションといえる水準かどうか で判断する（Ogawa \& Pongtanalert, 2011）のではなく, 製品成果を有用性や新規性という 2 つの概念に分けたり (Stock et al., 2015)，さらに，快楽主義的動機（Batra \& Ahtola, 1990; Dhar \& Wertenbrock, 2000; Voss et al., 2003) に対応した楽しさや興奮への期待などの概念を製品成果 に追加した調査が，将来の研究として望まれる。

第 2 に, 功利主義的モノづくり動機では充分に捉えき れていない，報酬や地位，名声や賞罰などの外的動機を 考慮した分析である。こうした外的動機の重要性は, ユー ザー・イノベーション研究において多く指摘される（e.g. Lakhani \& von Hippel, 2003; Ogawa \& Pongtanalert, 2013; von Krogh \& von Hippel, 2006)。Füller（2010）は, 名声 や金銭的報酬も動機になることを指摘し，とりわけ金銭 的報酬の提供は，消費者のアイデアを無料で搾取してい るイメージを払拭するために，消費者からの成果を求め ようとする企業にとって不可欠だという。同様に, メイ カーズ・ムーブメント研究においても, 名声や地位など の外的動機が指摘される (e.g. Baichtal, 2014; Dougherty \& Conrad, 2016)。本研究では, 研究の第一歩として, Stock et al.（2015）による功利主義的モノづくり動機を そのまま援用したが, 将来の研究では, その再検討が必 要であろう。

第 3 に, 変化する功利主義的・快楽主義的モノづくり 動機を捉えた，より複雑な分析である。Füller（2010） は，動機は時間とともに変化する可能性もあると指摘す る。プロジェクトへの参加当初は，完成した製品を自分 自身で使用することが動機であったが，長期的に参加す る事によって，プロジェクトに関与することの楽しみや， 周りの人との関わりが動機になることもあるという。こ うした動機の変化を捉えることは複雑だが, より功利主 義的・快楽主義的モノづくり動機と，製品成果・公開と の関係を明確にできる可能性がある。

\section{4. 結論}

本研究の結論としては，消費者の功利主義的モノづく り動機と快楽主義的モノづくり動機は, 製品成果および 公開に対して，それぞれ異なる影響を与えているという ことである。製品成果に対しては, 消費者の功利主義的 モノづくり動機が影響を与えるが，快楽主義的モノづく り動機は影響を与えていなかった。一方，製品公開に対 しては，消費者の快楽主義的モノづくり動機が影響を与 え, 功利主義的モノづくり動機によってその影響は強め られていた。

モノづくりをする消費者が増加する中，こうした異な る影響をもたらす消費者のモノづくり動機の理解を通し て, 消費者の製品成果 - 公開を上手く活用し，市場で成 果をあげる企業が増え, 消費者による製品成果が見過ご され埋もれてしまうことなく，社会全体で活用されるこ とを期待する。

\section{謝辞}

担当編集委員の古川一郎先生からの本特集への招待, および非常に有意義なコメントに対し，深く感謝する。 なお, 本研究は株式会社マクロミルの支援, およびJSPS 科研費 JP15H03393, JP16H03951 の助成を受けたもので ある。

注

1）製品を公開したサンプル $(\mathrm{n}=691)$ のうち，有料公開は 33 サンプル，無料公開は 658 サンプルであった。なお，有料 公開と無料公開サンプルの功利主義的モノづくり動機およ び快楽主義的モノづくり動機の平均值には, 有意な差はな かった。

2）因子負荷量が低かった 4 つの項目を削除した上で, 再び確 認的因子分析を行ったところ, $\mathrm{GFI}=0.95, \mathrm{CFI}=0.97$ とい う適合度の高いモデルを作成することができた。そして, 本稿と同様の手続きで分析を行ったが, その結果は本稿で 報告したものと変わらなかった。

\section{References}

Aiken, L., \& West, S. (1991). Multiple regression: Testing and interpreting interactions. California: SAGE Publications.

Amabile, T. (1985). Motivation and creativity: Effects of motivational orientation on creative writers. Journal of Personality and Social Psychology, 48(2), 393-399.

Anderson, C. (2012). Makers: New industrial revolution. New York: Crown Business.（関美和（訳）（2012）。MAKERS 21 世紀 


\section{の産業革命が始まる』NHK 出版）}

Bagozzi, R. P., \& Yi, Y. (1988). On the evaluation of structural equation models. Journal of the Academy of Marketing Science, 16(1), 74-94.

Baichtal, J. (2014). Maker pro: Essays on making a living as a maker. California: Maker Media.（野中モモ（訳）(2015)。『物 を作って生きるには一 23 人の Maker Pro が語る仕事と生活 一』オライリージャパン)

Batra, R., \& Ahtola, O. (1990). Measuring the hedonic and utilitarian sources of consumer attitudes. Marketing Letters, 2(2), 159-170.

Cohen, J., \& Cohen, P. (1983). Applied multiple regression/ correlation analysis for the behavioral sciences (2nd ed.). New Jersey: Lawrence Erlbaum Associates.

Cronbach, L. J. (1987). Statistical tests for moderator variables: Flaws in analyses recently proposed. Psychological Bulletin, 102(3), 414-417.

Csikszentmihalyi, M. (1996). Creativity: Flow and the psychology of discovery and invention. London: Harper Collins.

Deci, E. (1975). Intrinsic motivation. New York: Plenum Press. (安 藤延男 ·石田梅男（訳）（1980）。内発的動機づけ一実験社 会心理学的アプローチー』誠信書房)

Deci, E., \& Ryan, R. (1999). A meta-analytic review of experiments examining the effects of extrinsic rewards on intrinsic motivation. Psychological Bulletin, 125(6), 627-633.

Dhar, R., \& Wertenbroch, K. (2000). Consumer choice between hedonic and utilitarian goods. Journal of Marketing Research, 37(1), 60-71.

Dougherty, D., \& Conrad, A. (2016). Free to make: How the maker movement is changing our schools, our jobs, and our minds. California: North Atlantic Books. (金井哲生（訳）（2017）. 『私たちはみなメイカーだ：メイカーが変革する教育，仕 事, 社会, そして自分自身』オライリー・ジャパン)

Fornell, C., \& Larcker, D. F. (1981). Evaluating structural equation models with unobservable variables and measurement error. Journal of Marketing Research, 8(1), 39-50.

Franke, N., \& Shah, S. (2003). How communities support innovative activities: An exploration of assistance and sharing among end-users. Research Policy, 32(1), 157-178.

Füller, J. (2010). Refining virtual co-creation from a consumer perspective. California Management Review, 52(2), 97-112.

Füller, J., Jawecki G., \& Mühlbacher, H. (2007). Innovation creation by online basketball communities. Journal of Business Research, 60(1), 60-71.

Füller, J., Matzler, K., \& Hoppe, M. (2008). Brand community members as a source of innovation. Journal of Product Innovation Management, 25(6), 608-619.

Gershenfeld, N. (2005). Fab: The coming revolution on your desktop -from personal computers to personal fabrication. New York: Basic Books. (糸川洋（訳）（2012）、『Fab一パーソナルコン ピュータからパーソナルファブリケーションへ』オライリー ジャパン)

Hair, J. F., Black, W. C., Babin, B. J., \& Anderson, R. E. (2010). Multivariate data analysis: A global perspective, 7th ed.. New
Jersey: Pearson Education.

Halbinger, M. (2018). The role of makerspaces in supporting consumer innovation and diffusion: An empirical analysis. Research Policy, 47(10), 2028-2036.

Halverson, E., \& Sheridan, K. (2014). The Maker movement in education. Harvard Educational Review, 84(4), 495-504.

Hienerth, C., von Hippel, E., \& Jensen, M. B. (2014). User community vs. producer innovation development efficiency: A first empirical study. Research Policy, 43(1), 190-201.

Kwon, R. B., \& Lee, J. (2017). What makes a maker: The motivation for the maker movement in ICT. Information Technology for Development, 23(2), 318-335.

Lakhani, K., \& von Hippel, E. (2003). How open source software works: "free" user-to-user assistance. Research Policy, 32(6), 923-943.

Lakhani, K. R., \& Wolf, B. (2003). Why hackers do what they do: Under-standing motivation and effort in free/open source software projects. MIT Sloan Working Paper, 4425-03.

Leimeister, M. J., Huber, M., Bretschneider, U., \& Krcmar, H. (2009). Leveraging crowdsourcing: Activation-supporting components for IT-based ideas competition. Journal of Management Information Systems, 26 (1), 197-224.

Lilien, G., Morrison, P., Searls, K., Sonnack, M., \& von Hippel, E. (2002). Performance assessment of the lead user ideageneration process for new product development. Management Sciences, 48(8), 955-1101.

Martinez, L. S., \& Stager, G. (2013). Invent to learn: Making, tinkering, and engineering in the classroom. California: Constructing Modern Knowledge Press. (酒匂寛（訳） (2015)。『作ることで学ぶーMaker を育てる新しい教育のメ ソッド』オライリージャパン)

Nishikawa, H., \& Honjo, S. (2011). Tayousei no management: Crowdsourcing of Muji. Japan Marketing Journal, 30(3), 3549.（西川英彦・本條晴一郎（2011）。「多様性のマネジメン ト一無印良品のクラウドソーシングー」『マーケティング ジャーナル』30(3), 35-49) (In Japanese)

Nishikawa, H., Schreier, M., Fuchs, C., \& Ogawa, S. (2017). The value of marketing crowdsourced new products as such: Evidence from two randomized field experiments. Journal of Marketing Research, 54(4), 525-539.

Nishikawa, H., Schreier, M., \& Ogawa, S. (2013). User-generated versus designer-generated products: A performance assessment at Muji. International Journal of Research in Marketing, 30(2), 160-167.

Ogawa, S. (2013). User innovation: Shohisha kara hajimaru monodukuri no mirai. Tokyo: Toyo Keizai Inc. (小川進 (2013)。『ユーザーイノベーション一消費者から始まるモノ づくりの未来一』東洋経済新報社) (In Japanese)

Ogawa, S., \& Pongtanalert, K. (2011). Visualizing the invisible innovation continent: Evidence from global consumer innovation surveys. SSRN Working Paper. Retrieved from http:// ssrn.com/abstract $=1876186$ (March 1, 2019).

Ogawa, S., \& Pongtanalert, K. (2013). Exploring characteristics and motives of consumer innovators. Research-Technology 
Management, 56(3), 41-48.

Ryan, R., \& Deci, E. (2000). Intrinsic and extrinsic motivations: Classic definitions and new directions. Contemporary Educational Psychology, 25(1), 54-67.

Stock, M. R., Oliveira, P., \& von Hippel. E. (2015). Impacts of hedonic and utilitarian user motives on the innovativeness of user-developed solutions. Journal of Product Innovation Management, 32(3), 389-403.

von Hippel, E. (2005). Democratizing innovation. Boston: MIT Press.（サイコム・インターナショナル（訳）（2006）。民民 主化するイノベーションの時代一メーカー主導からの脱皮 一』ファーストプレス)

von Hippel, E., Ogawa, S., \& de Jong, J. (2011). The age of the consumer-innovator. MIT Sloan Management Review, 53(1), 27-35.

von Krogh, G., \& von Hippel, E. (2006). The promise of research on open source software. Management Science, 52(7), 975983.

Voss, K., Spangenberg, E., \& Grohmann, B. (2003). Measuring the hedonic and utilitarian dimensions of consumer attitude. Journal of Marketing Research, 40(3), 310-320.

Wolf-Powers, L., Doussard, M., Schrock, G., Heying, C., Eisenburger, M., \& Marotta, S. (2017). The maker movement and urban economic development. Journal of the American Planning Association, 83(4), 365-376.

Zheng, H., Li, D., \& Hou, W. (2011). Task design, motivation, and participation in crowdsourcing contests. International Journal of Electronic Commerce, 15(15), 57-88.

\section{岡田 庄生（おかだしょうお）}

法政大学大学院 経営学研究科博士後期課程。

修士 (経営学)。株式会社博報堂 (本務), 駒沢大学 (非常 勤講師)。法政大学大学院経営学研究科修士課程, 2019 年 3 月修了。

専門は, 消費者行動論, マーケティング・コミュニケーショ ン論。

\section{西川 英彦 (にしかわ ひでひこ)}

法政大学経営学部 兼大学院経営学研究科教授。

博士 (経営学)。株式会社ワールド, ムジ・ネット株式会社 取締役, 立命館大学経営学部准教授, 同教授を経て, 2010 年 4 月より現職。 